\title{
足背部に発生せる滑液膜肉腫の症例
}

\author{
山口県立医科大学整形外科教室 (主任: 服部奖教授)
}

山本一男長井淳

\section{A Case of Synovioma Occured in Left Foot}

By

\section{K. Yamamoto and A. Nagai}

Orthopedic Division, Yamaguchi Medical School.

1927年 Smith が滑液膜，粘液囊及び腱鞘から発生 する悪性腫湯に対して Synoviom なる名称を与えて 以来，欧米においては可成りの報告例をみるが，本邦 では比較的稀な疾患である.われわれも骨の破壊を伴 うSynoviom の1例を経験したので報告する.

症例 37 才, 男子.

主訴 左足背の疼痛性腫脹.

現病歴 入院の約 2 年 6 力月前外佰により左下腿, 足部に骨折を来たし, 左大腿から足尖ざ 1 力分半ギ プス固定を行なうも, 左足背部及び足底部に腫脹を残 していた． 6 力月後, 再び左足底部が扁平足様に腫脹 したが, レ線上異常定認めず, 疼痛む強度でないため 労動に従事していた. 入院 2 力月前, 左足背部にボ夕 が落ち左足背部の有痛性腫脹も溂次增大するため当科 に来院した。

入院時所見 体格, 栄養共に中等度なるも稍々贫血 を認む. 肺, 心, 腹に視侼㢷上異常を認めず. 心電図 上洞性速脈を認む。

局所々見 左足関節は軽度尖足位, 左下腿上 $1 / 3$ 外

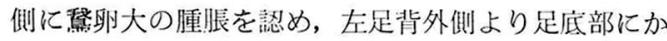
け強度に腫脹し, 足背部全体に静脈怒脹をみる. 更 に, 第 4 中足骨の走行に一致して約 $3 \mathrm{~cm}$ の手術創を 認む. 左下腿及び足部腫脹部に熱感, 波動などは認め ないが, 弾性硬で, 所々軟骨様便の部分が混在し, 第 4，5中足骨部に压痛を著明に認む. 運動制限は左全趾 に中等度と左足関節に怪度認む. なお左ソケイリンパ 腺は小豆大から拇指頭大に腫脹するむ圧痛は認めな 认.

レ線所見 第 4,5 中足骨中枢端を中心として, 吸 収性骨破壊像を認める. 第 4 中足骨中枢端が初発部位 と考えられ, その部は腫大した骨輪廓を痕跡的に止め
るのみで，末梢部まで，一部骨皮質を止めるだけで， 大部分の骨陰影は消失し，第 5 中足骨は中枢側 $1 / 2$ は 骨輪廓は腫大し，末梢との境界部が比較的鮮明なとこ

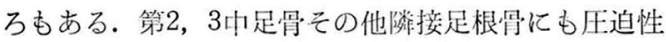

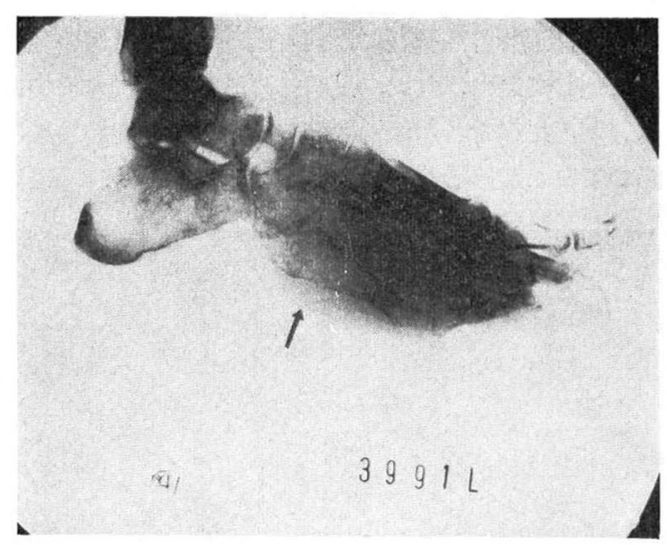

図 1

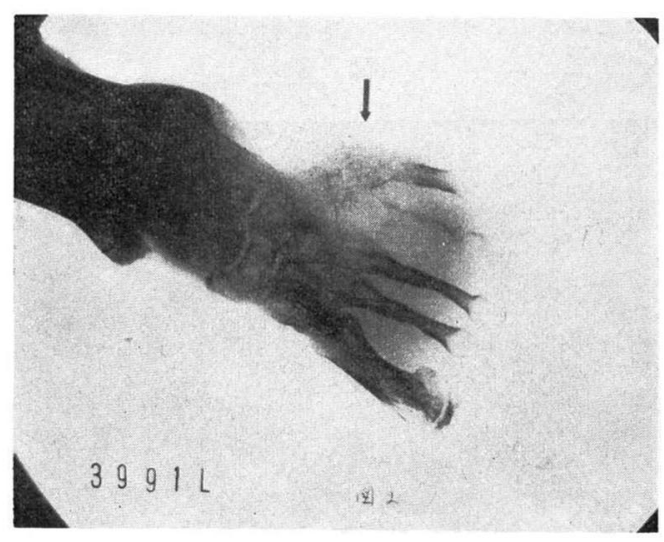

図 2 
破壊ないし所々に骨吸収性破壊像を認む. 又蜂窩状に 高度の破壊を認め，部分的飞骨皮質の消失をみる．末 梢部との境界は不鮮明. 軟部組織にも比較的境界鮮明 な棈円形，手拳大の腫湯陰影を認む. 胸 部には右上 下, 左全肺野に境界鮮明な大豆大加ら拇指頭大の円形 陰影を認む(図 1，2).

諸検査では赤血球数 $369 \times 10^{4}$, ヘマトクリット 33 $\%$, 白血球数 4,400 上柽度の貧血を認めるほか, 異常 を認めず。

手術所見 左下腿外側腫脤部を開くに, 長, 短腓骨 筋睷から, 被膜様組織で被われた淡黄白色ヂェリー様 腫煬塊を認む。迅速組織標本では次に述べる如く Synoviom 之晾断されたので, 大腿上中 $1 / 3$ 部で切断 し,リンパ腺清掃も行なつた. 左足背部より足底部に かけての腫瘍は被膜様組織で被われた淡黄白色ヂェリ 一様で, 第4，5中足骨は不規則に腫瑒により浸潤破壊 され中心部は一部塤死に陥り, 足部腫湯は足関節を一 て, 長, 短腓骨筋腱間に浸潤し, 下腿下部外側の腫汮 と交通していた。なお，足関節の滑液膜は侵されてい ないが, 足根骨各関節では骨破坮之腫湯細胞が壞死に 陷つていたため滑液膜の状態は不明であつた.

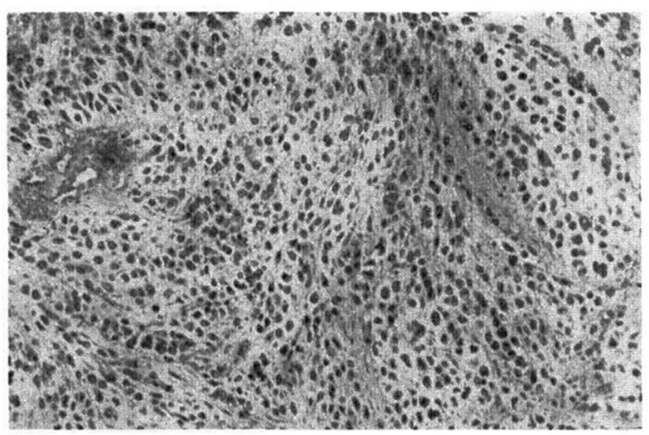

図 3

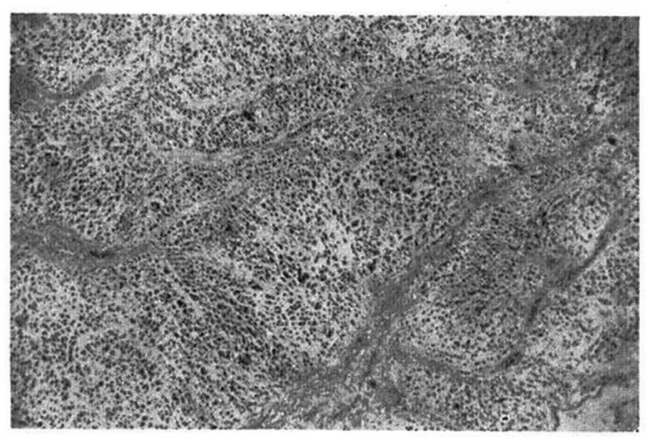

図 4
組織所見 細胞は明るく癌腫巣様を形成し, 立方又 は円形の細胞で偽腺梯構造を形成している部と, 細長 い細胞で不規則に走つた線維性肉腫様を呈する部を認 めた. なお PAS 染色も陽性で, 悪性滑液膜肉腫之㟝 䉼された(図 3，4).

術後経過 術後マイトマイシン (総量 $44 \mathrm{mg}$ ), ベー タートロン（総量 8,000r）を併用し, 後者は主として 右肺野に行なつた. 術後 3 力月義足を装着し歩行可能 となるも, 術後 5 力月頃より濑次鞀血, 顔面及び下肢 の浮腫をきたし，堅機能障害をきたしたため内科に転 棟加療するも, 術後 7 力月悪液質に宿り死亡す.

\section{考按}

Lejers-Rubens-Duval（1910）は滑液膜から発生す る腫掦を総括して独立せる腫場と考え, その特異性を 強調し, Smith (1927) はこの悪性腄場を Synoviom と呼称して以来, 欧米では Haagensen and Stout (1944) が 104 例, Bennett (1947) が 32 例なと比較 的多くの報告をみるが, 本邦においては四柳, 田上 （1942）の報告を噙矢とし，現在まで約 21 例を数え るに過ざず，本邦では比較的稀な疾患と思われる。 Ackerman（1954）ら多くの報告者によれば，Synoviom は関節, 腱鞘, 粘液鼠に接して発生するのが普 通であるが，滑液膜をおかすことは稀であるとしてい る. われわれの症例では立方, 中足関節附近から発生 したものと推定され，滑液膜の状態について足根骨相 互間の各関節の滑液膜は腫㻛組織の壊死などのため判 然としないが，滑液膜は侵されていたのではないかと 思われる. 発生部位は, Geschickter and Copeland ら及び本邦例によれば半数以上は滕関節部に発生し, Tillotson (1951)によれば, 滕, 足関節部, 大腿, 踵 部で $80.2 \%$ を占め, 次いで手, 骨艋, 臂部, 下腿, 讣関節部の顺之述べている. この上うに，本腫瘍は上 肢より下肢に多く, 本邦例 16 例中, 13 例 は下肢飞発 生している. 本症の外倠歴を文献的にみると, Santo, Bennett, Wright 及び本邦例では 15\% 30\%に外倠 歷を有し, われわれの症例も外㑺歴を有している. Santo らは外㑺により滑液膜炎を生じ，

本症発生の誘因となり得ると述べている. 年令的に は20４0才台に，性別では男子に 50６0％と女子ょ り多い.

本腫演の 臨床症状に 関しては, Geschickter and Copeland は疼痛, 腫脹, 四肢機能障害を挙げ, Jaffe 
は次第に増大する疼痛と腫瘤をあげ, Pack は臨床上 特有な症状は存在しないと述べている. 従つて, 臨木 症状のみから, 関節の近傍に発生する骨肉腫, 軟骨肉 腫，その他の悪性腫瘍との鑑別は困難な場合が少くな い. Lewis, Geschickter and Copeland, 筀らは本症 のレ線所見につき, 関節周辺の軟部組織に円形又は楕 円形の時として分葉状の比較的境界鮮明な腫瘍陰影を 認め, 特にこの腫瘍陰影内に不整形の散在せる濃厚な 石灰化梯陰影を認める場合は本腫瘍が疑わしいと述べ ており，レ線所見は他の悪性腫瘍との鑑別には必要で ある. しかし, われわれの症例では腫瘍陰影は認めた が, 石灰沈着はなく, 腫瘍による骨破堙像が著明であ り，このような骨破塤を示す症例はわれわれの調査し た範囲の文献では非常に少ないようである. かくの如 く，骨変化をきたした場合にはレ線上でも可成り鑑別 に困難をきたすむのと思われる．従つて最終的には組 織学的所見によらねばならない.だが組織学的にあ Chondrosarkom, Chondromyxosarkom など鑑別が 可成り困難な場合も少くない. Geschickter and Copeland 及び Jaffe は 1) 紡錘形細胞に富んだ細胞 間質が主体となり線維性肉腫様の様相を呈する部と,

2）上皮細胞に類似せる立方，柱状細胞が裂隙状，又 は腺様構造を有する組織が不規則に楽を形成する (pseudo glandular formation) 部との両者が存在す るととを挙げており, Bennett は 1) 組織の間隙形成 2）胞巢の形成，3）上皮様細胞の再生の 3 つの基本型 があると述べている. われわれの症例も Copeland and Geschickter 及び Bennett らの述べている所見 を認め, PAS 染色む陽性儿認めることから悪性洞液 膜肉腫と搒断された. 更に本症の悪性度に関しては, 全報告例亡む非常に悪性で殆んどが肺に転移坚を形成 し, 死の転帰をとる如く記載されている. 本症の悪性 度に関して Evans, 玉井らは間隙形成の少いこと, 腫 瘳細胞の異形性が強いとと, へモジデリン沈着, リポ イド呤喰細胞が著明でない程その悪性度が虽いとして おり，わ机われの症例でも組織の間陌形成が少なく， 腫瘍細胞の異型性が強い点から悪性度の強いもの之思 わ斻る。

以上の如く, 足関節に発生した悪性滑液膜肉腫がそ の腫㕫の増大と共に, 文献上非常に少ないレ線上骨佊 溒を伴つた症例を報告し, 併せて文献的考察を行なつ た.
本邦報告例（1942～1964） 発生部位別頻度

$\begin{array}{lllc}\text { 膝 } & \text { 関 } & \text { 節 } & 10 \text { 例 } \\ \text { 大 } & & \text { 腿 } & 3 \\ \text { 足 } & \text { 関 } & \text { 節 } & 3 \\ \text { 股 } & \text { 関 } & \text { 節 } & 1 \\ \text { 时 } & \text { 関 } & \text { 節 } & 1 \\ \text { 手 } & \text { 関 } & \text { 節 } & 1 \\ \text { 督 } & & \text { 部 } & 1 \\ \text { 指 } & \text { 関 } & \text { 節 } & 1 \\ \text { 不 } & & \text { 明 } & 1 \\ & \text { 計 } & & 22 \text { 例 }\end{array}$

（稿を終るにあたり，種々御便宜を晹つた山口学災病 院整形外科岡野部長, 終始御指獎を戴いた恩所服部奖 教授に深甚の謝意を表する.)

\section{参 考 文 献}

1) A. T. Aitken: Roentgenographic recognition of Synovioma,: J. B. J. S. vol. 23, 950, 1941.

2) Grauville $A$, Bennett: Malignant neoplasm originating in Synovial tissues. J. B. J. S. vol. 29, 259, 1947.

3) R. Winston Evans, G. E. Thomas and Norah M. Walker: A congenital malignant synovial tumor of bone J. B. J. S. vol. 42- B, 742, 1960.

4) Robert S, Sherman, and Florence. : A Roentgenographic study of Synovioma A. J. R. R. T. vol. 67, 80, 1952.

5) Geschickter and Copeland: Tumor of bone.

6) Lichtenstein: Bone Tumors. 1959.

7）長谷川貫一：整形外科. 11 巻, 477, 硈 35 .

8) 福原譲蔵：外科. 18 港, 579, 炤 31 .

9）五十嵐成男：日病会誌。45巻, 331 , 岹 31 .

10）宮地徽：臨床組織病理兴。 502 , 昭 31 .

11）中川三与. : 日整会誌. 27 巻, 363, 昭 28 .

12）田中昇：癌. 第 46 回, 253, 1955.

13）玉井恭子：整形外科. 10 巻, 534 , 昭 34 .

14）箱俊男: 整形外科. 13 巻, 937 , 炤 37.

\section{発 言 国立がんセンター 前山悠}

Synovial Sarcoma (Synovioma) は比較的少ない Tumor で我々あ最近手澄生し，切断したにあかか わらず現在肺に転移をさたした症例を経験した。

Benign Synovioma (pigmented villonodular synovitis)とは区别しなければならないのは無論であ る.鑑別はhistologisch に決めるだけで klinisch に は仲々困難です，benign と思つていても経過をみる と色々な所に転移する場合がある。 